\title{
3-nitrotyrosine levels in dichlorvos-induced neurotoxicity
}

\author{
Dilek Guvenç, Abdurrahman Aksoy, Yavuz Kursad Das, Enes Atmaca, and Oguzhan Yavuz \\ Department of Pharmacology and Toxicology, Faculty of Veterinary Medicine, Ondokuz Mayis University, Samsun, \\ Turkey
}

\author{
Received in June 2013 \\ CrossChecked in October 2013
}

Accepted in January 2014

\begin{abstract}
The aim of this study was to evaluate dichlorvos toxicity in terms of nitro-oxidative stress by determining 3-nitrotyrosine (3-NT) levels in the fore, mid, and hindbrain regions in acutely exposed rats. Male SpragueDawley rats were randomly allocated to three groups of eight. Group 1 was administered a single intraperitoneal dichlorvos dose of $1.8 \mathrm{mg} \mathrm{kg}^{-1}\left(0.1 \times \mathrm{xD}_{50}\right)$ and group 2 a dose of $9 \mathrm{mg} \mathrm{kg}^{-1}\left(0.5 \times \mathrm{xD}_{50}\right)$. The control group received $0.5 \mathrm{~mL}$ saline solution via the same route. 3 -NT and tyrosine (TYR) levels were measured using high performance liquid chromatography with a photodiode array detector (HPLC-PDA) and expressed as a ratio of 3-NT to TYR. The 3-NT/1000 TYR ratios increased significantly in the fore-, mid- and hindbrains of the exposed groups compared to control $(p<0.01)$. In the forebrain, the increase was also significant between the treated groups. Our study has confirmed that acute exposure to dichlorvos leads to nitro-oxidative stress in the brain and that 3-NT may play a role in the mechanism of dichlorvos neurotoxicity.
\end{abstract}

KEY WORDS: brain; HPLC; nitro-oxidative stress; pesticides; rats

Dichlorvos (DDVP-2,2-dichlorovinyl dimethyl phosphate) is a pesticide commonly used for the protection of stored products and grains, for controlling ecto- and endoparasites of farm animals, and for combating indoor and outdoor pests. Its annual world production reaches four thousand tonnes (1). Being an organophosphorous compound, its principal mechanism of toxicity is through the inhibition of acetylcholinesterase (AChE) and/or neuropathy target esterase (NTE), which acts on the central and peripheral nervous systems (2).

In addition, dichlorvos toxicity seems to induce oxidative stress $(3,4)$, whose product peroxynitrite (5) may react with various amino acid residues in proteins (6). The product of tyrosine nitration is 3 -nitrotyrosine (3-NT), and it is often used as a biomarker of oxidative attack on biological molecules $(6,7)$. However, research evaluating OP-induced oxidative stress in terms of 3-NT levels is limited. The aim of our study was to contribute to the scarce information about 3-NT measurements in the brain and to see how dichlorvos affects its levels through oxidative stress.

\section{MATERIALS AND METHODS}

\section{Reagents}

Analytical grade chemicals, standards, and solvents were obtained from Sigma-Aldrich (St. Louis, MO, USA).

\section{Animals and treatment}

Prior to the experiment, all the experimental procedures were approved by the Experimental Animal Studies Ethics Committee of Ondokuz Mayis University in Samsun, Turkey.

Twenty-four male Sprague-Dawley rats (250$300 \mathrm{~g}$ ), maintained in a climate-controlled room at $22 \pm 2{ }^{\circ} \mathrm{C}$ on a $12 \mathrm{~h}$ light/dark cycle and receiving standard pellet diet and water ad libitum, were 
randomly allocated to three groups of eight animals. Group 1 received a single intraperitoneal (i.p.) dose of $1.8 \mathrm{mg} \mathrm{kg}^{-1}\left(0.1 \times \mathrm{xD}_{50}\right)$ of dichlorvos, group 2 $9 \mathrm{mg} \mathrm{kg}^{-1}\left(0.5 \mathrm{xLD}_{50}\right)$, and the control group received $0.5 \mathrm{~mL}$ of saline solution via the same route (1). No rat showed visual signs of toxicity or died because of treatment. Three days after dichlorvos or saline administration, the rats were killed by cervical dislocation and brain specimens stored at $-80^{\circ} \mathrm{C}$ until analysis.

\section{Sample preparation}

3-NT levels were expressed as $\mu \mathrm{mol} \mathrm{L} \mathrm{L}^{-1}$ per $1000 \mu \mathrm{mol} \mathrm{L} \mathrm{L}^{-1}$ of tyrosine (3-NT/1000 TYR) to normalise for differing brain concentrations of tyrosine $(8,9)$. Calibration curves were produced for 3-NT and TYR. The standard calibration curves were linear over

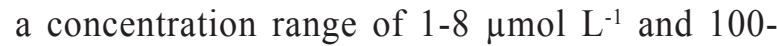
$1000 \mu \mathrm{mol} \mathrm{L}^{-1}$ for 3-NT and TYR, respectively. Frozen brain samples were sonicated in $10 \mathrm{mmol} \mathrm{L}^{-1}$ of cold sodium acetate at $\mathrm{pH} 6.5$ and protein concentrations were determined using the Bradford method (10). Homogenised brain samples $\left(5 \mathrm{mg} \mathrm{mL}^{-1}\right)$ were centrifuged at $14,000 \mathrm{~g}$ and $4{ }^{\circ} \mathrm{C}$ for $10 \mathrm{~min}$. The supernatant was collected and treated with $10 \mathrm{mg} \mathrm{mL}^{-1}$ Pronase (Streptomyces griseus protease) at $50{ }^{\circ} \mathrm{C}$ for $18 \mathrm{~h}$. After incubation, samples were treated with a $10 \%$ volume of $60 \%$ of trichloroacetic acid (TCA) and centrifuged at $14,000 \mathrm{~g}$ and $4{ }^{\circ} \mathrm{C}$ for $10 \mathrm{~min}$. The supernatant was removed and passed through a $0.2 \mu \mathrm{m}$ polyvinylidene difluoride (PVDF) membrane, and the filtrate was analysed with high performance liquid chromatography with a photodiode array detector HPLC-PDA (11-13).

\section{High-performance liquid chromatography (HPLC)}

The HPLC system (Shimadzu, LC-20AT Prominence, Kyoto, Japan) consisted of a pump, an auto-injector (SIL-20AC), and a diode array detector (SPD-M20A). 3-NT and TYR were separated in a $5 \mu \mathrm{m}, 4.6 \times 250 \mathrm{~mm} \mathrm{C}_{18}$ reverse phase (Inertsil ${ }^{\circledR}$ ODS3, GL Sciences Inc. Tokyo, Japan) with $5 \mu \mathrm{m}$, 4x20 mm guard columns (GL Sciences Inc. Tokyo, Japan). The mobile phase was $50 \mathrm{mmol} \mathrm{L}^{-1}$ sodium acetate / $10 \%$ methanol (v/v) at $\mathrm{pH} 4$.2. It was filtered through a $0.2 \mu \mathrm{m}$ PVDF membrane and degassed in an ultrasonic bath (Wise Clean, WUC-AO3 H, Korea). The flow rate was $0.8 \mathrm{~mL} \mathrm{~min}^{-1}$ and PDA detection was performed at $278 \mathrm{~nm}(11,13,14)$. The retention times of 3-NT and TYR standards were 35.560 and $10.364 \mathrm{~min}$, respectively. The average percentage of the recoveries of 3-NT and TYR were estimated at $92 \%$ and $90 \%$, respectively. The limits of detection were $6.7 \mathrm{nmol} \mathrm{L}{ }^{-1}$ for 3-NT and $35 \mathrm{nmol} \mathrm{L}^{-1}$ for TYR.

\section{Statistical analysis}

Means \pm standard deviations (SD) of the measured parameters were analysed using the SPSS version 20 (IBM corp., Armonk, NY, USA). Differences between the groups were determined using the analysis of variance (ANOVA), followed by post-hoc testing (Tukey's honestly significant difference - Tukey HSD), and the level for statistical significance was set at $p<0.01$.

\section{RESULTS AND DISCUSSION}

Table 1 shows mean 3-NT/1000 TYR ratios in the brain regions for each group. The 3-NT/1000 TYR ratio increased significantly $(p<0.01)$ in group 1 and 2 compared to control. In the forebrain, this increase was also significant between the treated groups. However, the within-group differences between brain regions were not significant.

Our study confirms increased brain nitration markers from studies with other OP pesticides such as malathion (15) and chlorpyrifos (16). In contrast, Kose et al. (17) concluded that acute dichlorvos administration did not cause marked oxidative stress in rat heart and that oxidative stress probably did not play a major role in dichlorvos-induced poisoning. However, our study suggests that dichlorvos may cause oxidative stress-mediated neurotoxicity.

Table 1 Mean $\pm S D$ values of 3-NT/1000 TYR in different brain regions following dichlorvos treatment

\begin{tabular}{lccc}
\multicolumn{1}{c}{ Groups } & Forebrain & Midbrain & Hindbrain \\
\hline Control & $0.053 \pm 0.019^{\mathrm{a},{ }^{*}}$ & $0.056 \pm 0.028^{\mathrm{a},{ }^{*}}$ & $0.047 \pm 0.020^{\mathrm{a},{ }^{*}}$ \\
Dichlorvos $1.8 \mathrm{mg} \mathrm{kg}^{-1}$ & $0.480 \pm 0.255^{\mathrm{b},{ }^{*}}$ & $0.533 \pm 0.348^{\mathrm{b}, *}$ & $0.466 \pm 0.246^{\mathrm{b},{ }^{*}}$ \\
Dichlorvos $9.0 \mathrm{mg} \mathrm{kg}^{-1}$ & $0.972 \pm 0.168^{\mathrm{c},{ }^{*}}$ & $0.580 \pm 0.365^{\mathrm{b}, *}$ & $0.655 \pm 0.369^{\mathrm{b},{ }^{*}}$ \\
\hline
\end{tabular}

Each group comprised 8 rats

$a, b, c$ - values with different superscripts in the same column are significantly different $(\mathrm{p}<0.01)$

${ }^{*}{ }^{-}$values are not significantly different between the rows ( $\left.\mathrm{p}>0.05\right)$. 
Neuromediator and enzyme levels vary in different brain regions. For example, AChE levels, which mediate OP neurotoxicity in the cholinergic pathways, vary in different areas of the brain. High free radical levels and deficient antioxidant defence mechanisms make specific brain regions more susceptible to OP neurotoxicity (18-20). Although the 3-NT level in our study increased in the fore, mid- and hindbrain relative to dose, statistically that increase was not significant between the treated groups in the mid- and hindbrain regions. This suggests that this may be due to different levels of enzyme, neuromediator, and antioxidant defence mechanisms in different parts of the brain.

Even though our study is limited to single-doseinduced nitrative stress in the brain, it has confirmed that 3-NT may play a role in the mechanism of dichlorvos neurotoxicity. Further studies with different doses and different experimental designs, such as chronic toxicity and/or comparisons between dichlorvos and other OPs could help to elucidate the mechanisms which mediate dichlorvos neurotoxicity.

\section{Acknowledgments}

This study was supported by the Commission of Scientific Research Projects of Ondokuz Mayis University (Project No: PYO.VET.1901.10.002). The authors wish to thank Gregory T. Sullivan for editing the English in this manuscript.

\section{REFERENCES}

1. World Health Organization (WHO). Environmental Health Criteria 79: Dichlorvos. [displayed 15 April 2013]. Available at http://www.inchem.org/documents/ehc/ehc/ ehc79.htm

2. Allen SL. Regulatory aspects of acute neurotoxicity assessment. In: Krieger R, editor. Hayes' handbook of pesticide toxicology. $3^{\text {rd }}$ ed. Oxford: Elsevier Ltd; 2010. p. 586-602.

3. Franco R, Li S, Rodriguez-Rocha H, Burns M, Panayiotidis MI. Molecular mechanism of pesticide-induced neurotoxicity: Relevance to Parkinson's disease. Chem Biol Interact 2010;188:289-300. doi: 10.1016/j.cbi.2010.06.003

4. Soltaninejad K, Abdollahi M. Current opinion on the science of organophosphate pesticides and toxic stress: a systematic review. Med Sci Monit 2009;15:RA75-90. PMID: 19247260

5. Szabo C. Multiple pathways of peroxynitrite cytotoxicity. Toxicol Lett 2003;140-141:105-12. doi: 10.1016/S03784274(02)00507-6

6. Abello N, Kerstjens HAM, Postma DS, Bischoff R. Protein tyrosine nitration: selectivity, physicochemical and biological consequences, denitration, and proteomics methods for the identification of tyrosine-nitrated proteins. J Proteome Res 2009;8:3222-38. doi: 10.1021/pr900039c
7. Ischiropoulos H, Beckman JS. Oxidative stress and nitration in neurodegeneration: cause, effect, or association? J Clin Invest 2003;111:163-9. doi: 10.1172/JCI17638

8. Althaus JS, Schmidt KR, Fountain ST, Tseng MT, Carroll RT, Galatsis P, Hall ED. LC-MS/MS detection of peroxynitrite-derived 3-nitrotyrosine in rat microvessels. Free Radic Biol Med 2000;29:1085-95. PMID: 11121715

9. He Y, Imam SZ, Dong Z, Jankovic J, Ali SF, Appel SH, Le $\mathrm{W}$. Role of nitric oxide in rotenone-induced nigro-striatal injury. J Neurochem 2003;86:1338-45. doi: 10.1046/j.1471-4159.2003.01938.x

10. Bradford MA. Rapid and sensitive method for the quantitation of microgram quantities of protein utilizing the principle of protein-dye binding. Anal Biochem 1976;72:248-54. PMID: 942051

11. Hensley K, Maidt ML, Yu Z, Sang H, Markesbery WR, Floyd RA. Electrochemical analysis of protein nitrotyrosine and dityrosine in the Alzheimer brain indicates region-specific accumulation. J Neurosci 1998;18:8126-32. PMID: 9763459

12. Imam S, Ali S. Selenium, an antioxidant, attenuates methamphetamine induced dopaminergic toxicity and peroxynitrite generation. Brain Res 2000;855:186-91. PMID: 10650149

13. Walker IM, Walker PD, Imam SZ, Ali SF, Mayeux PR. Evidence for peroxynitrite formation in renal ischemiareperfusion injury: studies with the inducible nitric oxide synthase inhibitor L-N6-(1-Iminoethyl) lysine. J Pharmacol Exp Ther 2000;295:417-22. PMID: 10992009

14. Abu-Qare AW, Suliman HB, Abou-Donia MB. Induction of urinary excretion of 3-nitrotyrosine, a marker of oxidative stress, following administration of pyridostigmine bromide, $\operatorname{DEET}(\mathrm{N}, \mathrm{N}$-diethyl-m-toluamide) and permethrin, alone and in combination in rats. Toxicol Lett 2001;121:127-34. PMID: 11325563

15. Ranjbar A, Ghahremani MH, Sharifzadeh M, Golestani A, Ghazi-Khansari M, Baeeri M, Abdollahi M. Protection by pentoxifylline of malathion-induced toxic stress and mitochondrial damage in rat brain. Hum Exp Toxicol 2010;29:851-64. doi: 10.1177/0960327110363836

16. Mehta A, Verma SR, Srivastava N. Chlorpyrifos induced alterations in the levels of hydrogen peroxide, nitrate and nitrite in rat brain and liver. Pest Biochem Physiol 2009;94:55-9. doi. 10.1016/j.pestbp.2009.04.001

17. Kose A, Gunay N, Kose B, Ocak AR, Erel O, Demiryurek AT. Effects of atropine and pralidoxime pretreatment on serum and cardiac oxidative stress parameters in acute dichlorvos toxicity in rats. Pest Biochem Physiol 2010;97:249-55. doi: 10.1016/j.pestbp.2010.03.004

18. Bajgar J, Hajek P, Slizova D, Krs O, Fusek J, Kuca K, Jun $\mathrm{D}$, Bartosova L, Blaha V. Changes of acetylcholinesterase activity in different rat brain areas following intoxication with nerve agents: biochemical and histochemical study. Chem Biol Interact 2007;165:14-21. doi: 10.1016/j. cbi.2006.10.006

19. Gokulrangan G, Zaidi A, Michaelis ML, Schöneich C. Proteomic analysis of protein nitration in rat cerebellum: effect of biological aging. J Neurochem 2007;100:1494-504. doi: $10.1111 /$ j.1471-4159.2006.04334.x

20. Kazi AI, Oommen A. Monocrotophos induced oxidative damage associates with severe acetylcholinesterase inhibition in rat brain. Neurotoxicology 2012;33:156-61. doi: $10.1016 /$ j.neuro.2012.01.008 


\section{Sažetak}

\section{Razine 3-nitrotirozina kod neurotoksičnosti izazvane diklorvosom}

Cilj je ovog ispitivanja bio ocijeniti neurotoksičnost diklorvosa kroz nitrooksidativni stres mjerenjem razina 3-nitrotirozina (3-NT) u prednjem, središnjem i stražnjem režnju mozga akutno izloženih mužjaka štakora Sprague-Dawley, koji su u tu svrhu nasumce bili podijeljeni u tri skupine po osam životinja. Skupina 1 primila je jednokratnu intraperitonealnu dozu diklorvosa od $1,8 \mathrm{mg} \mathrm{kg}^{-1}\left(0,1 \mathrm{xLD}_{50}\right)$, a skupina 2 dozu od $9 \mathrm{mg} \mathrm{kg}^{-1}\left(0,5 \mathrm{xLD}_{50}\right)$. Kontrolna je skupina primila $0,5 \mathrm{~mL}$ fiziološke otopine, također intraperitonealno. Razine 3-NT-a i tirozina (TIR) izmjerene su tekućinskim kromatografom visoke djelotvornosti s detektorom s nizom dioda (HPLC-PDA) te su izražene kao omjer 3-NT:TIR. Omjeri 3-NT/1000 TIR značajno su se povećali u svim režnjevima izloženih skupina ( 1 i 2 ) u odnosu na kontrolnu skupinu $(p<0,01)$. Povećanje je također bilo značajno u prednjem režnju skupine 2 u odnosu na skupinu 1, ali nije bilo značajne razlike između izloženih skupina u ostalim režnjevima. Naše je istraživanje potvrdilo da akutna izloženost diklorvosu dovodi do nitrooksidativnog stresa u mozgu te da 3-NT sudjeluje u mehanizmu neurotoksičnosti diklorvosa.

KLJUČNE RIJEČI: HPLC; mozak; nitrooksidativni stres; pesticidi; štakori

\section{CORRESPONDING AUTHOR:}

Dilek Guvenç

Ondokuz Mayıs University Faculty of Veterinary Medicine Department of Pharmacology and Toxicology

Atakum, 55139, Samsun, Turkey

E-mail:dguvenc@omu.edu.tr 